\title{
PENGARUH FAKTOR INTERNAL DAN \\ EKSTERNAL TERHADAP TINGKAT KOMPLAIN PENGGUNA KARTU KREDIT DI DAERAH ISTIMEWA YOGYAKARTA
}

\author{
AWAN SANTOSA \\ Program Studi Manajemen Universitas Mercu Buana Yogyakarta \\ Email: awansantosa@gmail.com
}

RAHMAHARATI ESA PUTRI

Program Studi Manajemen Universitas Mercu Buana Yogyakarta Email: esa.putri@yahoo.com

Abstrak

Penelitian ini bertujuan untuk mengetahui pengaruh faktor internal dan faktor eksternal terhadap tingkat komplain pengguna kartu kredit dengan indikator informasi, sarana, SOP, ketidaktahuan, kecerobohan dan fraud di Daerah Istimewa Yogyakarta.

Penelitian ini dilakukan dengan menggunakan teknik Purposive Random Sampling. Sampel yang diambil sebanyak 100 responden dari para pengguna kartu kredit Daerah Istimewa Yogyakarta dengan pendekatan Tabachinik dan Fidel. Pengumpulan data diambil dengan menggunakan metode kuesioner tertutup dengan menggunakan skala Likert.

Berdasarkan hasil penelitian diketahui bahwa terdapat pengaruh faktor internal dan faktor eksternal terhadap tingkat komplain pengguna kartu kredit dengan persamaan regresise bagai berikut: $Y=4,828-0,118 . X_{1}+0,267 . X_{2}+$ $0,038 . X_{3}+0,470 . X_{4}+0,208 . X_{5}+0,259 . X 6$. Berdasarkan analisis data statistik, indikator-indikator pada penelitian ini bersifat valid dan variabelnya bersifat reliabel. Pada pengujian asumsi klasik, model regresi bebas multikolonieritas, tidak terjadi heteroskedastisitas, dan berdistribusi normal.

Urutan secara individu dari masing-masing variabel yang paling berpengaruh adalah variabel ketidaktahuan dengan koefisien regresi sebesar 0,470; sarana dengan koefisien regresi sebesar 0,267; fraud dengan koefisien regresi sebesar 0,259; kecerobohan dengan koefisien regresi sebesar 0,208; SOP dengan koefisien regresi sebesar 0,038danvariabel yang berpengaruh paling rendah adalah informasi dengan koefisien regresi sebesar -0,118.

Dengan demikian bank penerbit kartu kredit perlu mempertahankan elemenelemen yang sudah dinilai baik oleh pengguna kartu kredit serta perlu memperbaiki hal-hal yang masih kurang baik khususnya di Daerah Istimewa Yogyakarta.

Kata kunci: faktor internal dan factor eksternal, informasi, sarana, SOP, ketidaktahuan, kecerobohan, fraud dan tingkat komplain

\section{PENDAHULUAN}


Kondisi persaingan saat ini semakin tinggi antar perusahaan khususnya bank, saling bersaing untuk meningkatkan pelayanannya. Sebagai perusahaan yang menyediakan produk jasa perbankan harus mampu memberikan pelayanan prima. Karena dengan itu kebutuhan masyarakat dalam bidang ekonomi semakin meningkat dan berkembang. Hal ini menyebabkan masyarakat menyadari peranan sebuah bank sangat penting dalam melakukan kegiatan-kegiatan yang berkaitan dengan perekonomian. Kondisi inilah yang menimbulkan persaingan di industri perbankan semakin tinggi. Masing-masing bank bersaing untuk mendapatkan kemudahan dan keuntungan bagi nasabah dalam melakukan transaksi perbankan. Salah satu produk yang ditawarkan saat ini oleh pihak perbankan yaitu kartu kredit (credit card) yang merupakan produk yang mempermudah dalam melakukan transaksi perbankan. Kartu kredit saat ini seperti sudah menjadi kebutuhan pokok bagi kehidupan masyarakat kita bahkan seluruh dunia khususnya bagi yang hidup diperkotaan.

Perkembangan dalam industri jasa perbankan menyebabkan persaingan penerbit kartu kredit menjadi sangat ketat, antara lain membuat iklan melalui media masa dan elektronik. Selain itu banyaknya penawaran-penawaran menarik yang di berikan oleh pihak penerbit kartu kredit mulai dari tawaran hadiah-hadiah atau tawaran bebas iuran kartu dua tahun pertama bahkan seumur hidup untuk menarik minat nasabahnya. Penggunaan kartu kredit di Indonesia mulai berkembang setelah deregulasi perbankan dengan diterbitkan Surat Keputusan Menteri Keuangan Nomor 1251/KMK013/1988 tanggal 26 Desember 1988 mengenai bisnis kartu kredit yang digolongkan sebagai kelompok usaha pembiayaan. Oleh karena itu instansi perbankan maupun non bank baik nasional mapun internasional sangat antusias bersaing untuk menerbitkan kartu kredit dan berlomba-lomba memberikan penawaran jasa-jasa perkreditan, khususnya kredit konsumtif. Penerbit kartu kredit internasional yang mengembangkan jaringannya di Indonesia yaitu Visacard International dan Mastercard International yang berkerjasama dengan bank-bank nasional dalam merebut pangsa pasar. Perkembangan yang pesat di ikuti oleh beberapa penerbit kartu kredit lainnya, antara lain BCA, HSBC, BNI, BNI, BRI, Bank Mandiri, Bank Danamon, GE Finance, Standard Chartered, Bank Niaga dan lain-lain. Pada dasarnya semua penerbit kartu kredit memberikan penawaran dan beragam fasilitas serta memudahkan pemegang kartu kredit dalam bertransaksi. Tentunya disesuaikan dengan kebutuhan masing-masing individu dan harus digunakan dengan bijak.

Kartu kredit merupakan alat pembayaran pengganti uang tunai yang dapat digunakan oleh konsumen untuk ditukarkan dengan barang atau jasa yang diinginkan di tempat-tempat yang dapat menerima pembayaran dengan menggunakan kartu kredit (merchant). Kartu kredit juga dapat diartikan sebagai salah satu fasilitas dari perbankan yang memudahkan transaksi nasabah. Dengan cara menggesek atau mendipkan credit card pada mesin edisi (edc) dan selanjutnya melakukan pembayaran setelah tanggal cetak tagihan. Baik tagihan lembar fisik ( hardcopy) yang dikirimkan melalui kurir ke alamat surat menyurat yaitu alamat rumah atau kantor atau pun e-statement yang dikirimkan via email.

Dibandingkan dengan jenis kredit konsumsi lain yang ditawarkan oleh bank, kartu kredit merupakan jenis kredit yang mudah disetujui. Syarat pengajuan kartu kredit berupa fotokopi KTP, slip gaji bagi karyawan, SPT (surat pajak tahunan), SKP (surat keterangan penghasilan) dan persyaratan lain yang dianggap perlu. 
Bahkan pada perkembangan saat ini, apabila calon pemegang kartu kredit yang mengajukan permohonan kartu kredit telah memiliki kartu kredit sebelumnya, maka calon pemegang kartu kredit yang bersangkutan hanya perlu menyerahkan fotokopi tagihan kartu kredit tersebut.

Namun terjadinya permasalahan dimana pihak penerbit kartu kredit seakan begitu mudah menyetujui aplikasi kartu kredit sedangkan pada kenyataannya nasabah tidak diinfokan secara mendetail, seakan nasabah merasa dirugikan oleh pihak Bank.

Selain kemudahan dalam mengajukan permohonan, kelebihan kartu kredit adalah lingkup penggunaannya yang sangat luas, dari transaksi kecil sampai transaksi besar. Hal ini sangat bermanfaat bagi masyarakat, terutama bagi mereka yang mobile sangat membutuhkan alat transaksi ini. Sebagai penyedia media pembayaran berkerjasama dengan pusat-pusat perbelanjaan atau pun merchant melalui promo-promo menarik, pihak kartu kredit melakukan penawaran tentunya dengan program diskon, bonus, cicilan dengan bunga rendah bahkan $0 \%$ serta keunggualan-keunggulan lainnya membuat setiap orang ingin memiliki kartu kredit dengan apply (mendaftar). Semua penawaran dibuat dengan lebih menarik lagi. Semakin sering digunakan, semakin besar peluang mendapatkan hadiah. Namun apakah dengan berhutang akan mendapatkan banyak keuntungan?

Di sisi lain, sekarang juga semakin banyak keluhan dari para pengguna kartu kredit. Secara garis besar, masalah-masalah pemegang kartu kredit bisa dikelompokkan beberapa hal.

1. Faktor internal, seperti : informasi yang tidak disampaikan secara lengkap oleh pihak customer service bank penerbit, kerusakan sarana dan prasarana yang disediakan pihak bank seperti mesin ATM / mesin edc, standar pelayanan atau SOP yang berjalan tidak sesuai contohnya pada pengiriman lembar tagihan baik softcopy maupun hard copy dan pengiriman kartu yang melampaui batas yang telah ditentukan. Dari faktor ekternal, seperti: nasabah yang awam pada penggunaan kartu kredit, kecerobohan nasabah yang mengakibatkan kartu hilang atau ada penyalahgunaan transaksi kartu kredit. Selain keuntungannya, pemegang kartu kredit biasanya juga dihadapkan dengan masalah jumlah hutang yang semakin besar. Hal ini terjadi karena pembayaran hutang yang dilaksanakan hanya pembayaran minimum saja, sementara penggunaan kartu kredit sebagai alat pembayaran transaksi semakin meningkat.

2. Bank belum terlalu optimal dan responsif dalam menangani kartu kredit. Ketika ada keluhan, bank cenderung 'defence' nasabahlah yang harus proaktif mengenai kartu kreditnya, dan pemegang kartu kredit merasa diabaikan.

3. Adanya teror dari debt collector (baik secara halus atau kasar) yang bertubi-tubi akibat ketidakmampuan nasabah membayar tunggakan tagihan kartu kreditnya. Bahkan, terkadang keluarga turut menjadi disasaran teror.

4. Dimasukkannya pemegang kartu kredit dalam daftar hitam BI (Bank Indonesia) akibat tunggakan kredit yang belum clear mengenai kesalahan para pihak. Dampaknya, pemegang kartu kredit tidak bisa memperoleh fasilitas kredit (kartu kredit, KPR, KTA dan lain-lain) dari bank manapun.

\section{BATASAN MASALAH}

Batasan masalah dalam penelitian ini adalah: 
1. Faktor internal dalam penelitian ini di batasi pada faktor informasi, sarana dan SOP. Sedangkan faktor eksternal dalam penelitian ini dibatasi pada faktor ketidaktahuan, kecerobohan dan indikasi penyalahgunaan (fraud).

2. Wilayah dalam penelitian ini dibatasi pada pengguna kartu kredit yang berdomisili di Daerah Istimewa Yogyakarta.

3. Responden dalam penelitian ini dibatasi pada pengguna kartu kredit yang telah menggunakan kartu kredit lebih dari 6 bulan.

\section{Rumusan Masalah}

Berdasarkan latar belakang yang telah dikemukakan, maka secara spesifik penulis dapat mengidentifikasi ke dalam beberapa masalah yang diuraiakan ke dalam bentuk rumusan masalah sebagai berikut:

1. Bagaimana pengaruh faktor internal yang meliputi informasi, sarana dan SOP serta faktor eksternal yang meliputi ketidaktahuan, kecerobohan dan indikasi penyalahgunaan (fraud) baik secara parsial dan simultan terhadap tingkat komplain pengguna kartu kredit di Daerah Istimewa Yogyakarta.

2. Diantara variabel faktor internal yang meliputi informasi, sarana dan SOP serta faktor eksternal yang meliputi ketidaktahuan, kecerobohan dan indikasi penyalahgunaan (fraud) manakah yang paling dominan dalam mempengaruhi tingkat komplain pengguna kartu kredit di Daerah Istimewa Yogyakarta.

\section{Tujuan Penelitian}

Adapun tujuan dari penulisan skripsi ini adalah sebagai berikut:

1. Untuk mengetahui pengaruh faktor internal yang meliputi informasi, sarana dan SOP serta faktor eksternal yang meliputi ketidaktahuan, kecerobohan dan indikasi penyalahgunaan (fraud) baik secara parsial dan simultan terhadap tingkat komplain pengguna kartu kredit di Daerah Istimewa Yogyakarta.

2. Untuk mengetahui diantara variabel faktor internal yang meliputi informasi, sarana dan SOP serta faktor eksternal yang meliputi ketidaktahuan, kecerobohan dan indikasi penyalahgunaan (fraud) manakah yang paling dominan dalam mempengaruhi tingkat komplain pengguna kartu kredit di Daerah Istimewa Yogyakarta.

\section{LANDASAN TEORI}

\section{Kredit dan Kartu Kredit}

Perkataan "kredit" telah lazim digunakan pada praktik perbankan dalam pemberian berbagai fasilitas yang berkaitan dengan pinjaman. Kata yang sama dijumpai pula dalam penerbitan kartu yang dikeluarkan oleh lembaga keaungan, baik Bank atau Lembaga Keuangan Bukan Bank (LKBB), secara mandiri ataupun berkerjasama.

Pengertian "kredit" dalam penggunaan yang semakin meluas perlu untuk ditelusuri, sejauh mana relevansi penggunaannya dalam praktik bisnis umumnya dan perbankan khususnya.

Kata "kredit" berasal dari bahasa Romawi "credere" yang berarti percaya atau "credo" atau "creditum" yang berarti saya percaya. (Ibrahim, Johanes 2004).

Kartu kredit merupakan alat pembayaran pengganti uang tunai yang dapat digunakan oleh konsumen untuk ditukarkan dengan barang dan jasa yang diinginkan di tempat-tempat yang dapat menerima pembayaran dengan menggunakan kartu kredit (merchant). Kartu kredit 
juga dapat diartikan sebagai salah satu fasilitas perbankan yang memudahkan transaksi nasabah.

\section{Komplain}

Komplain adalah bentuk ekspresi negatif yang dihasilkan dari ketidaksesuaian antara kenyataan dengan keinginan seseorang (James : 2006). Menurut Burhanudin 2006 komplain adalah tanggapan yang disebabkan oleh ketidakpuasan yang dirasakan seseorang ketika melakukan pembelian. Sedangkan menurut Tjiptono 2004 komplain adalah ungkapan kekecewaan atau ketidakpuasan.

Menurut Bell dan Luddington (2006), keluhan pelanggan (customercomplaints) adalah umpan balik (feedback) dari pelanggan yang ditujukan kepada perusahaan yang cenderung bersifat negatif. Umpan balik ini dapat dilakukan secara tertulis atau secara lisan.

Perilaku komplain konsumen adalah istilah yang mencakup semua perilaku konsumen yang berbeda bila mereka merasa tidak puas dengan suatu pembelian (Singh, 1988).

Beberapa hal yang mendasari konsumen mengajukan komplain adalah karena konsumen merasa kecewa oleh produsen dan tidak mendapatkan pelayanan yang memuaskan. Banyak perusahaan yang terbukti kurang memperhatikan kinerja penanganan komplain pelanggan.

\section{Faktor Internal dan Eksternal}

Internal dan ekternal berasal dari bahasa inggris intern dan ekstern.

1) Faktor internal

Pengertian internal adalah menyagkut bagian dalam. Dan pengertian faktor internal adalah faktor yang berasal dari dalam diri seseorang atau perusahaan dalam mencipta dan menemukan sesuatu.

2) Faktor eksternal

Pengertian eksternal adalah yang menyangkut bagian luar dari sesuatu. Dan pengertian faktor eksternal adalah faktor yang berasal dari luar diri seseorang atau perusahaan dalam mencipta dan menemukan sesuatu.

\section{Hipotesis}

Berdasarkankerangkapenelitian di atas, makahipotesisdalampenelitianiniadalah :

a. Diduga Informasi berpengaruh negatif dan signifikan terhadap tingkat komplain pengguna kartu kredit di Daerah Istimewa Yogyakarta.

b. Diduga Sarana berpengaruh negatif dan signifikan terhadap tingkat komplain pengguna kartu kredit di Daerah Istimewa Yogyakarta.

c. Diduga SOP berpengaruh negatif dan signifikan terhadap tingkat komplain pengguna kartu kredit di Daerah Istimewa Yogyakarta.

d. Diduga Ketidaktahuan berpengaruh positif dan signifikan terhadap tingkat komplain pengguna kartu kredit di Daerah Istimewa Yogyakarta.

e. Diduga Kecerobohan berpengaruh positif dan signifikan terhadap tingkat komplain pengguna kartu kredit di Daerah Istimewa Yogyakarta.

f. Diduga Fraudberpengaruh positif dan signifikan terhadap tingkat komplain pengguna kartu kredit di Daerah Istimewa Yogyakarta.

g. Diduga Informasi, Sarana, SOP, Ketidaktahuan, Kecerobohan dan Fraudberpengaruh signifikan secara simultan terhadap tingkat komplain pengguna kartu kredit di Daerah Istimewa Yogyakarta. 


\section{KERANGKA PIKIR}

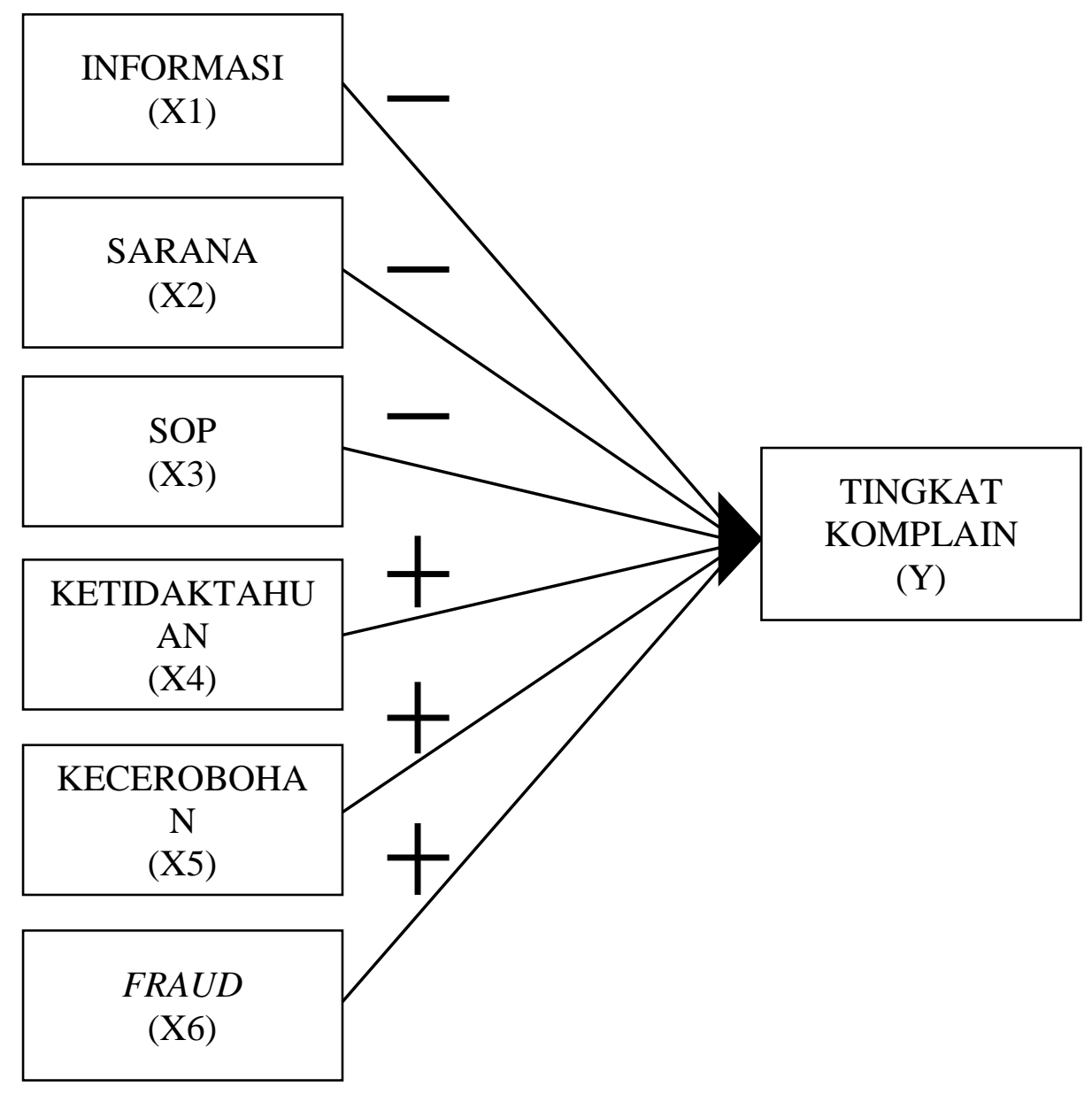

\section{METODE PENELITIAN}

\section{Populasi}

Populasi bukanlah hanya orang tetapi juga obyek dan benda-benda alam yang lain. Populasi juga bukan sekedar jumlah yang ada pada obyek yang dipelajari, tetapi meliputi seluruh karakteristik atau sifat yang dimiliki oleh subyek atau obyek itu dan sampel merupakan bagian dari populasi tersebut.

Populasi menurut Sugiono (2006) adalah "Wilayah generalisasi yang terdiri atas obyek atau subyek yang mempunyai kualitas dan karakteristik tertentu yang ditetapkan oleh peneliti untuk dipelajari dan kemudian ditarik kesimpulannya".

Populasi dalam penelitian ini adalah pengguna kartu kredit di Daerah Istimewa Yogyakarta yang menggunakan kartu kredit lebih dari 6 bulan yang jumlahnya sulit untuk diketahui secara pasti.

\section{Sampel}

Sampel merupakan sebagian dari populasi yang terdiri atas sejumlah anggota yang dipilih dari populasi. Dengan kata lain sejumlah, tetapi tidak semua, elemen populasi akan membentuk sampel (Sekaran, 2006). Menurut Ferdinand (2006), sampel adalah subset dari populasi, terdiri dari beberapa anggota populasi. Subset ini diambil karena dalam banyak 
kasus tidak mungkin kita meneliti seluruh anggota populasi, oleh karena itu kita membentuk sebuah perwakilan populasi yang disebut sampel.

Dalam penelitian ini, pengambilan sampel menggunakan pendekatan Tabachinik dan Fidel (1998). Menurut Ferdinand (dikutip dalam Anggraini, 2009) pengambilan sampel dengan tehnik Tabachinik dan Fide/ adalah jumlah variabel independen dikalikan dengan 10 sampai 25 jumlah variabel independen dalam penelitian ini adalah 6, sehingga jumlah sampel yang dibutuhkan berada pada kisaran 60 sampai 160.Agar jumlah sampel lebih proporsional, maka jumlah sampel yang diambil adalah 100 sampel.

Teknik pengambilan sampel yang digunakan dalam penelitian ini adalah purposive random sampling yaitu pengambilan sampel dengan tidak memberi kesempatan yang sama kepada seluruh anggota populasi serta menetapkan tujuan tertentu pada sampelnya. Karakteristik subyek serta menetapkan tujuan tertentu pada sampelnya. Karakteristik subyek yang ditetapkan sebagai kriteria populasi adalah pengguna yang berusia di atas 17 tahun dan dibawah 50 tahun yang menggunakan kartu kredit di Daerah Istimewa Yogyakarta yang telah menggunakan kartu kredit lebih dari 6 bulan.

\section{HASIL PENELITIAN}

Sebagaimana telah diuraikan dalam Bab II, bahwa dalam penelitian ini diajukan 6 hipotesis yang untuk selanjutnya akan dibuktikan kebenarannya atas dasar hasil pengujian. Dari hasil perhitungan diperoleh hasil sebagai berikut: :

1. Informasi $\left(X_{1}\right)$ tidak berpengaruh secara signifikan terhadap tingkat komplain pada pengguna kartu kredit di Daerah Istimewa Yogyakarta. Hal ini ditunjukkan oleh nilai sig $\mathrm{t}$ hitung $(0,375)>0,05$.

2. Sarana $\left(X_{2}\right)$ berpengaruh secara positif dan signifikan terhadap tingkat komplain pada pengguna kartu kredit di Daerah Istimewa Yogyakarta. Hal ini ditunjukkan oleh nilai sig $\mathrm{t}$ hitung $(0,025)<0,05$.

3. SOP $\left(\mathrm{X}_{3}\right)$ tidak berpengaruh secara signifikan terhadap tingkat komplain pada pengguna kartu kredit di Daerah Istimewa Yogyakarta. Hal ini ditunjukkan oleh nilai sig t hitung $(0,778)>0,05$.

4. Ketidaktahuan $\left(\mathrm{X}_{4}\right)$ berpengaruh secara positif dan signifikan terhadap tingkat komplain pada pengguna kartu kredit di Daerah Istimewa Yogyakarta. Hal ini ditunjukkan oleh nilai sig t hitung $(0,000)<0,05$.

5. Kecerobohan $\left(X_{5}\right)$ berpengaruh secara positif dan signifikan terhadap tingkat komplain pada pengguna kartu kredit di Daerah Istimewa Yogyakarta. Hal ini ditunjukkan oleh nilai sig t hitung $(0,031)<0,05$.

6. Fraud $\left(\mathrm{X}_{6}\right)$ berpengaruh secara positif dan signifikan terhadap tingkat komplain pada pengguna kartu kredit di Daerah Istimewa Yogyakarta. Hal ini ditunjukkan oleh nilai sig $\mathrm{t}$ hitung $(0,020)<0,05$.

\section{KESIMPULAN}

Berdasarkan hasil penelitian dan pembahasan pada bab V, maka dapat diambil beberapa kesimpulan sebagai berikut:

1. Terdapat pengaruh yang signifikan antara variabel Informasi, Sarana, SOP, Ketidaktahuan, Kecerobohan dan Fraud secara simultan terhadap tingkat komplain pada 
pengguna kartu kredit di Daerah Istimewa Yogyakarta. Hal ini dibuktikan dari nilai signifikansi pada nilai uji $\mathrm{F}<0,05$.

2. Tidak terdapat pengaruh yang signifikan variabel informasi secara parsial terhadap tingkat komplain pada pengguna kartu kredit di Daerah Istimewa Yogyakarta. Hal ini ditunjukkan dari nilai signifikansi pada nilai uji t $>0,05$.

3. Terdapat pengaruh yang signifikan variabel sarana secara parsial terhadap tingkat komplain pada pengguna kartu kredit di Daerah Istimewa Yogyakarta. Hal ini ditunjukkan dari nilai signifikansi pada nilai uji $t<0,05$.

4. Tidak terdapat pengaruh yang signifikan variabel SOP secara parsial terhadap tingkat komplain pada pengguna kartu kredit di Daerah Istimewa Yogyakarta. Hal ini ditunjukkan dari nilai signifikansi pada nilai uji $t>0,05$.

5. Terdapat pengaruh yang signifikan variabel ketidaktahuan secara parsial terhadap tingkat komplain pada pengguna kartu kredit di Daerah Istimewa Yogyakarta. Hal ini ditunjukkan dari nilai signifikansi pada nilai uji $t<0,05$.

6. Terdapat pengaruh yang signifikan variabel kecerobohan secara parsial terhadap tingkat komplain pada pengguna kartu kredit di Daerah Istimewa Yogyakarta. Hal ini ditunjukkan dari nilai signifikansi pada nilai uji $t<0,05$.

7. Terdapat pengaruh yang signifikan variabel fraud secara parsial terhadap tingkat komplain pada pengguna kartu kredit di Daerah Istimewa Yogyakarta. Hal ini ditunjukkan dari nilai signifikansi pada nilai uji $t<0,05$.

8. Pengaruh paling dominan variable bebas terhadap variabel terikat adalah pengaruh variabel ketidaktauan karena koefisien betanya (Standardized Coefficients) paling besar dibandingkan lainnya yaitu 0,470.

\section{SARAN}

Adapun saran yang dapat peneliti sampaikan berdasarkan hasil yang peneliti temukan adalah sebagai berikut:

1. Informasi

Selalu memberikan informasi sesuai dengan kebutuhan nasabah seperti informasi tanggal cetak tagihan dan jatuh tempo untuk menghindari terjadinya keterlambatan pembayaran yang menyebabkan munculnya bunga. Serta melakukan konfirmasi kepada nasabah untuk memastikan apakah informasi yang diberikan sudah diterima dengan baik atau belum

\section{Sarana}

Disarankan bagi pihak penerbit kartu kredit untuk selalu melakukan pemeliharaan sarana dan prasarana yang tersedia secara berkesinambungan. Serta melakukan evaluasi dan inovasi yang disesuaikan dengan perkembangan teknologi terkini terhadap sarana dan prasarana yang telah ada sehingga dapat memberikan pelayanan kepada pemilik kartu kredit secara maksimal.

3. SOP

Selalu konsisten dalam menjalankan SOP yang ada sehingga mekanisme tetap berjalan sesuai dengan alur sehingga ketika terjadi permasalahan mudah untuk mendapatkan solusi yang diberikan. Serta selalu meningkatkan pemahaman bagi pegawai Bank terhadap SOP, sehingga nasabah mendapatkan informasi yang sejelas-jelasnya.

4. Ketidaktahuan 
Melakukan seleksi pada nasabah yang mengajuakan aplikasi kartu kredit, terutama bagi calon pengguna kartu kredit baru (pemula) bagi pihak analis Bank penerbit untuk meminimalisir terjadinya kredit macet. Serta memberikan edukasi dan sosialisasi kepada nasabah terhadap informasi produk kartu kredit secara transparan dan menyeluruh tanpa ada sedikitpun yang di tutup - tutupi sehingga nasabah mendapatkan gambaran yang jelas terhadap makanisme tata cara dan ketentuan penggunaan kartu kredit.

5. Kecerobohan

Disarankan bagi pihak penerbit untuk selalu memberikan edukasi untuk menumbuhkan kesadaran kepada nasabah akan pentingnya menjaga keamanan data-data pribadinya terhadap pihak luar termasuk pihak Bank untuk mencegah terjadinya hal - hal yang tidak diinginkan dikemudian hari. Serta disarankan kepada pengguna kartu kredit untuk selalu memperhatikan keberadaan kartu kredit seperti dalam penyimpanan dan pemeliharaan kartu kredit.

6. Fraud

Menerapakan sistem transaksi yang lebih aman, seperti penggunaan pin, kode transaksi pada setiap transaksi. Serta memberikan notifikasi atau konfirmasi ke nomor nasabah pada setiap transaksi bukan hanya pada transaksi yang terindikasi mencurigakan.

\section{DAFTAR PUSTAKA}

Aditama Yoga Tjandra, 2010, Manajemen Administrasi Rumah Sakit, UI-Press, Jakarta.

Alfionita, Nikke.2013. Pengaruh Kualitas Pelayanan Terhadap Kepuasan Nasabah Pada Pt. Bank Sumut Cabang Usu.Skirpsi. Fakultas Ekonomi dan Bisnis, Universitas Sumatera Utara, Medan.

Arikunto, S. 2006. Prosedur Penelitian Suatu Pendekatan Praktik, Jakarta : Rineka Cipta.

Ascarintya, Praveda.2011. "Analisis Pengaruh Kualitas Pelayanan Terhadap Kepuasan Nasabah (Studi Pada Nasabah Debitur Pt.Bpr Satria Pertiwi Semarang)." Skripsi. Program Studi Strata 1 Manajemen, Fakultas Ekonomi Universitas Diponegoro, Semarang.

Augusty, Ferdinand. 2006. Metode Penelitian Manajemen: Pedoman Penelitian untuk skripsi, Tesis dan Disertai IImu Manajemen. Semarang: Universitas Diponegoro.

Bandu, Yunus. 2013. Pengaruh Kualitas Pelayanan Terhadap Kepuasan Pelanggan pada PT. PLN (Persero) Rayon Makassar Barat. Skirpsi, Fakultas Ilmu Sosial Dan Ilmu Politik, Universitas Hasanuddin.

Darmadi Durianto, Sugiarto, Tony Sitinjak.2004. Strategi Menaklukan Pasar melalui Riset. Ekuisitas dan Prilaku Merek, Jakarta: Gramedia.

Fachrozi, Arief. 2014. Pengaruh Kualitas Pelayanan Terhadap Kepuasan Pelanggan Grapari Telkomsel Sun Plaza Medan. Skripsi. Fakultas Ekonomi Dan Bisnis, Universitas Sumatra Utara, Medan. 
Ghozali, Imam, 2009. Aplikasi Analisis Multivariate Dengan Program SPSS, Edisi Keempat, Penerbit Universitas Diponegoro.

Ghozali, Imam. 2011. "Aplikasi Analisis Multivariate Dengan Program SPSS". Semarang: Badan Penerbit Universitas Diponegoro.

Indarti, Gusti Ayu Eka, 2012. "Pengaruh Kualitas Pelayanan Jasa terhadap Kepuasan Nasabah Pada PT. Bank Negara Indonesia (Persero) TBK Kantor Cabang Utama (KCU) Palembang". Jurnal Ekonomi dan Informasi Akuntansi (Jenius).

Iqbal, Hasan. 2006, Analisis Data Penelitian Dengan Statistik. Jakarta : PT Bumi Aksara.

Kotler, Philip. 2008. Manajemen Pemasaran Edisi 12 Jilid 2. Jakarta: Indeks.

Kotler, Philip, dan Kevin Lane Keller. 2009. Manajemen Pemasaran Jilid 1, edisi Ketiga Belas, Terjemahan Bob Sabran, MM. Jakarta: Penerbit Erlangga.

Kotler, Philip, dan Kevin Lane Keller. 2009. Manajemen Pemasaran Jilid 2, edisi Ketiga Belas, Terjemahan Bob Sabran, MM. Jakarta: Penerbit Erlangga.

Kotler Phillip, Kevin Lance Keller. 2012. Marketing Management 14th edition. Jakarta:PT. Indeks Kelompok Gramedia.

Muchlis, Vidya Asnita. 2012. Pengaruh Dimensi Kualitas Layanan Terhadap Tingkat Kepuasan Nasabah Pada Pt.Bank Rakyat Indonesia (Persero) Tbk, Cabang Ahmad Yani Makassar. Skripsi, Fakultas Ekonomi dan Bisnis. Universitas Hasanuddin.

Notoatmodjo, S. 2010. Metodologi Penelitian Kesehatan. Jakarta : Rineka Cipta.

Pratiknya, A. W., 2008, Dasar-Dasar Metodologi Penelitian Kedokteran dan Kesehatan, Raja Grafindo Persada, Jakarta.

Sugiyono. 2006. "Metode Penelitian Kuantitatif Kualitatif dan R\&D". Bandung: Alfabeta.

Sugiyono, (2008). Metode Penelitian Kunatitatif Kualitatif dan R\&D. Bandung Alfabeta.

Sugiyono. (2009). Metode Penelitian Bisnis (Pendekatan Kuantitatif, Kualitatif, dan R\&D). Bandung: Alfabeta.

Sugiyono. 2012. Metode Penelitian Kuantitatif Kualitatif dan R\&D. Bandung: Alfabeta.

Tjiptono, Fandy. 2007, Strategi Pemasaran. Edisi ke dua, penerbit Andi, Yogyakarta.

Tjiptono, Fandy. (2014). Pemasaran Jasa. Jakarta: Gramedia Cawang.

Uma Sekaran, 2006, Metodologi Penelitian untuk Bisnis, Edisi 4, Buku 1, Jakarta: Salemba Empat 